\title{
PERILAKU REMAJA PUTRI TENTANG DIET DI SMA NEGERI 5 PEKANBARU
}

\author{
Andriani \\ STIKes Payung Negeri Pekanbaru \\ Korespondensi: andriani.lecturer@gmail.com
}

\begin{abstract}
Background: Diet is aiming to lose weight can be done in various ways.During the adolescent anxiety problems against weight loss arising more happens than the other.The physical changes that occur in particular weight and body shape increases the risk of someone worrying about her weight. Purpose: This research was conducted aiming to know the behavior of young women about diet in SMA Negeri 5 Pekanbaru. Methods: This research is quantitative type with anlitik design with coss sectional approach. This type of research is quantitative and deskriftif design. The population of this research as much as 444 people with 82 samples of respondents with the method of sampling Simple Random Sampling using univariate analysis.This research instrument using questionnaires and engineering research with primary data. Results: Based on the results of research that young women in SMA Negeri 5 Pekanbaru knowledgeable low as much as 42 respondents (51\%), being negative as much as 43 respondents (52\%), and the actions that go on a diet as much as 58 respondents (71\%). Conclusion: The majority of respondents at SMA Negeri 5 Pekanbaru have low knowledge about diet, positive attitude about diet and dieting.
\end{abstract}

Keywords: Behavior; Young women; Diet

\begin{abstract}
ABSTRAK
Latar Belakang: Diet merupakan usaha yang bertujuan untuk menurunkan berat badan yang dapat dilakukan dengan berbagai cara. Pada masa remaja masalah kecemasan terhadap berat badan timbul lebih banyak terjadi dibandingkan masa kehidupan lainnya. Perubahan fisik yang terjadi khususnya berat badan dan bentuk tubuh meningkatkan risiko seseorang mencemaskan berat badannya. Tujuan: Penelitian ini dilakukan bertujuan untuk mengetahui perilaku remaja putri tentang diet di SMA Negeri 5 Pekanbaru. Metode: Jenis penelitian ini bersifat kuantitatif dan berdesain deskriftif. Populasi penelitian ini sebanyak 444 orang dengan sampel 82 responden dengan metode pengambilan sampel Simple Random Sampling dengan menggunakan analisa univariat. Instrumen penelitian ini menggunakan kuesioner dan teknik penelitian ini dengan data primer. Hasil: Berdasarkan hasil penelitian bahwa remaja putri di SMA Negeri 5 Pekanbaru berpengetahuan rendah sebanyak 42 responden (51\%), bersikap positif sebanyak 43 responden (52\%), dan tindakan yang melakukan diet sebanyak 58 responden (71\%). Kesimpulan: Responden di SMA Negeri 5 Pekanbaru mayoritas memiliki pengetahuan rendah tentang diet, sikap positif tentang diet dan melakukan diet.
\end{abstract}


Kata kunci: Perilaku; Remaja putri; Diet

\section{PENDAHULUAN}

Menurut World Health Organization (WHO) masa remaja terbagi atas masa remaja awal berusia 10-13 tahun, masa remaja tengah berusia 14-16 tahun dan masa remaja akhir berusia 17-19 tahun (Probosari: 2014.) Masa remaja merupakan suatu periode dalam rentang kehidupan manusia. Remaja umumnya mengalami pergolakan hidup yang diakibatkan oleh berbagai macam perubahan, baik fisik, psikis maupun sosial. Perubahan fisik pada remaja merupakan perubahan yang paling kelihatan menonjol, dan juga salah satu sumber permasalahan utama pada remaja. Salah satu permasalahan utama yang dihadapi oleh remaja, khususnya remaja putri, adalah berat badan dan penampilan diri (Lintang: 2015).

Penampilan merupakan suatu hal yang sering kali mendapat perhatian khusus, dan setiap individu berusaha agar penampilanya terlihat sempurna di lingkungan sosialnya. Hal ini sangat wajar, mengingat salah satu dari lima kebutuhan dasar manusia menurut maslow adalah kebutuhan akan penghargaan diri. Jika kebutuhan harga diri dan penghargaan dari orang lain tidak terpenuhi, individu tersebut akan merasa tidak berdaya dan merasa rendah diri atau minder (Abdurrahman:2014).

Hal yang umum dilakukan wanita dalam menjaga penampilan adalah pengaturan pola makan, Salah satu upaya upaya untuk menurunkan berat badan yang popular dikalangan remaja saat ini adalah perilaku diet. Diperkirakan sekitar (73\%) remaja melakukan diet untuk menurunkan berat badan mereka. Diet adalah usaha sadar orang dalam membatasi dan mengontrol makanan yang akan dimakan dengan tujuan untuk mengurangi atau mempertahankan berat tubuh (Abdurrahman:2014).

Pada saat memasuki masa remaja, seorang perempuan mengalami peningkatan lemak tubuh sehingga tubuh mereka menjadi tidak ideal dan akhirnya membuat mereka merasa tidak puas terhadap tubuh. Sejalan dengan penelitian yang dilakukan oleh Levine \& Smolak (2005) yang menyatakan bahwa 40-70\% 
remaja perempuan merasakan ketidakpuasan pada dua atau lebih dari bagian tubuhnya, khususnya pada bagian pinggul, pantat, perut dan paha (Hanum:2014).

Diet yang ditempuh remaja sering kali tidak diperhitungkan dampak negatifnya. Hal ini disebabkan karena keinginan remaja dalam melakukan diet tidak melalui bimbingan seorang ahli seperti dokter dan ahli gizi. Diet yang ditempuh remaja sering tidak sesuai dengan aturan kesehatan, mereka hanya memikirkan bagaimana menjadi kurus dengan cepat dan mudah tanpa melihat akibat yang akan ditimbulkan oleh diet yang dilakukan (Abdurrahman: 2014).

Diet dapat dilakukan dengan cara yang benar dan sehat, namun juga tidak jarang yang melakukannya dengan cara yang tidak sehat. Diet yang sehat adalah dengan mengkonsumsi makanan yang sehat dan menambah aktifitas fisik secara wajar. Sedangkan diet yang tidak sehat adalah diet yang dilakukan lewat beberapa cara yaitu: dengan sengaja melewatkan waktu makan, minum obat pelangsing, dan muntah dengan sengaja (Hanum:2014).

Penelitian yang dilakukan Neumark pada 4746 remaja di SMP dan SMA di St. Paul dan Mineapolis negara bagian Amerika Serikat, didapatkan prevalensi perilaku diet dengan cara tidak sehat pada remaja putri 56,9\% dan remaja putra $32,7 \%$. Penelitian tersebut menunjukkan remaja yang memiliki status gizi lebih cenderung berusaha menurunkan berat badan dibandingkan dengan remaja yang memiliki status gizi normal dan remaja putri lebih tinggi persentasi menurunkan berat badan dibandingkan remaja putra (Alhadar et al, 2014). Secara khusus, di Indonesia belum ada angka yang pasti mengenai perilaku diet pada remaja. Prediksi yang didasarkan pada data rata-rata pravelensi remaja di Indonesia ditemukan angka sebesar 42,6\% (Ayuningtyas et al., 2012)

SMA NEGERI 5 Pekanbaru merupakan salah satu sekolah menengah atas favorit yang berada di kota Pekanbaru. Letak SMA NEGERI 5 Pekanbaru yang berada di pusat kota mengakibatkan sangat berkembangnya informasi dan gaya hidup yang beraneka ragam. Perilaku mengenai diet dan penampilan fisik tidak terlepas dari pengaruh sosiokultural yang berkembang di lingkungan tempat tinggal remaja, dalam beberapa hal remaja merasa tidak puas dengan bentuk tubuhnya. Tingginya arus komunikasi dan informasi di kota yang begitu cepat serta mudah diperoleh dibandingkan di desa mengakibatkan pengaruh yang lebih 
besar terhadap perilaku remaja. Interprestasi remaja dari media massa mendorong mereka untuk melakukan diet.

Survey awal yang dilakukan di SMA 5 NEGERI Pekanbaru berjumlah 10 responden menggunakan kuesioner, terdapat $60 \%$ responden yang melakukan diet.

Berdasarkan penjelasan tersebut perlu adanya penelitian untuk mengetahui gambaran perilaku remaja putri tentang diet di SMA NEGERI 5 Pekanbaru.

\section{TUJUAN}

Penelitian ini dilakukan bertujuan untuk mengetahui perilaku remaja putri tentang diet di SMA Negeri 5 Pekanbaru

\section{METODE}

Jenis penelitian yang digunakan pada penelitian ini adalah kuantitatif dengan desain deskriptif. Dalam penelitian ini melihat gambaran perilaku remaja terhadap diet di SMA Negeri 5 Pekanbaru. Lokasi penelitian ini dilakukan di SMA Negeri 5 Pekanbaru pada bulan Februari-April 2018 dan telah mendapatkan izin riset/ penelitian No:800/Disdik/1.3/2018/2990. Populasi adalah keseluruhan objek yang diteliti. Populasi dalam penelitian ini adalah seluruh siswi SMA Negeri 5 Pekanbaru, yaitu berjumlah 444 orang, dengan jumlah sampel 82 orang yang diambil secara simple random sampling yaitu cabut undi, Pengumpulan data untuk mengukur tingkat pengetahuan, sikap dan tindakan dilakukan dengan cara mengisi kuesioner, untuk mengetahui IMT menggunakan alat pengukur tinggi badan dan berat badan .

\section{HASIL}

\section{Data Umum}

Tabel 1. Distribusi Frekuensi Remaja Putri Berdasarkan Informasi Tentang Diet

\begin{tabular}{cccc}
\hline No & Informasi & Frekuensi & Persentase \\
\hline 1 & Mendapatkan informasi & 82 & $100 \%$ \\
2 & Tidak Mendapatkan Informasi & 0 & 0 \\
\hline & Jumlah & 82 & $100 \%$ \\
\hline
\end{tabular}

Sumber : Analisis Data Primer Kuisioner 
Tabel 2. Distribusi Frekuensi Remaja Putri Berdasarkan Sumber Informasi Tentang Diet

\begin{tabular}{cccc}
\hline No & Sumber Informasi & Frekuensi & Presentase \\
\hline 1 & Media massa & 69 & $84,1 \%$ \\
2 & Tenaga kesehatan & 6 & $7,3 \%$ \\
3 & Masyarakat & 7 & $8,6 \%$ \\
\hline & Jumlah & 82 & $100 \%$ \\
\hline
\end{tabular}

Sumber : Analisis Data Primer Kuisioner

Tabel 3. Distribusi Frekuensi Remaja Putri Berdasarkan Saran Orang Tua Tentang Diet

\begin{tabular}{cccc}
\hline No & Saran Orang Tua & Frekuensi & Presentase \\
\hline 1 & Ya & 52 & $63 \%$ \\
2 & Tidak & 30 & $37 \%$ \\
\hline
\end{tabular}

Sumber : Analisis Data Primer Kuisioner

Tabel 4. Distribusi Frekuensi Remaja Putri Berdasarkan Indeks Massa Tubuh Tentang Diet

\begin{tabular}{cccc}
\hline No & IMT & Frekuensi & Presentase \\
\hline 1 & Underweight & 5 & $6 \%$ \\
2 & Normal & 24 & $29 \%$ \\
4 & Beresiko & 25 & $30 \%$ \\
5 & Obes I & 24 & $29 \%$ \\
6 & Obes II & 2 & $4 \%$ \\
\hline
\end{tabular}

Sumber : Analisis Data Primer Kuisioner

\section{Data Khusus}

Tabel 5. Distribusi Frekuensi Remaja Putri Berdasarkan Pengetahuan Tentang Diet

\begin{tabular}{cccc}
\hline No & Pengetahuan & Frekuensi & Persentase \\
\hline 1 & Tinggi & 40 & $49 \%$ \\
2 & Rendah & 42 & $51 \%$ \\
\hline & Jumlah & 82 & $100 \%$ \\
\hline
\end{tabular}

Sumber : Analisis Data Primer Kuisioner 
Dari tabel 5, hasil penelitian menunjukkan bahwa dari 82 responden di dapat mayoritas remaja putri berpengetahuan rendah tentang diet yaitu sebanyak 42 responden $(51 \% \%)$.

Tabel 6. Distribusi Frekuensi Remaja Putri Berdasarkan Sikap Tentang Diet

\begin{tabular}{cccc}
\hline No & Pengetahuan & Frekuensi & Persentase \\
\hline 1 & Positif & 43 & $52 \%$ \\
2 & Negatif & 39 & $48 \%$ \\
\hline & Jumlah & 82 & $100 \%$ \\
\hline
\end{tabular}

Sumber : Analisis Data Primer Kuisioner

Dari tabel 6, hasil penelitian menunjukkan bahwa, dari 82 responden di dapatkan mayoritas remaja putri menunjukkan sikap positif tentang diet yaitu sebanyak 43 responden $(52 \%)$.

Tabel 7. Distribusi Frekuensi Remaja Putri Berdasarkan Tindakan Diet

\begin{tabular}{cccc}
\hline No & Tindakan & Frekuensi & Persentase \\
\hline $\mathbf{1}$ & Ya melakukan & 58 & $71 \%$ \\
$\mathbf{2}$ & Tidak melakukan & 24 & $29 \%$ \\
\hline & Jumlah & 82 & $100 \%$ \\
\hline
\end{tabular}

Sumber : Analisis Data Primer Kuisioner

Dari tabel 7, hasil penelitian menunjukkan bahwa dari 82 responden didapatkan mayoritas melakukan diet yaitu sebanyak 58 responden $71 \%$ ).

\section{PEMBAHASAN}

Pengetahuan merupakan hasil dari tahu, dan ini terjadi setelah seseorang melakukan penginderaan terhadap suatu objek tertentu. Ada beberapa faktor yang mempengaruhi pengetahuan antara lain yaitu pendidikan, pekerjaan, umur dan informasi. Informasi bisa mempengaruhi pengetahuan rendah tetapi jika ia mendapatkan informasi yang baik dari media seperti tv, radio, internet, surat kabar maka hal ini dapat meningkatkan pengetahuan seseorang (Wawan, 2011).

Hasil penelitian ini sejalan dengan hasil penelitian yang dilakukan Rahmi dengan Judul Pengaruh Teman Sebaya, Pengetahuan, Media Masa Terhadap Perilaku Diet Mahasiswi Stikes Payung Negeri Pekanbaru Tahun 2014, yang menunjukkan 
bahwa mayoritas $62 \%$ responden memiliki tingkat pengetahuan diet yang rendah, sedangkan responden yang memiliki tingkat pengetahuan diet yang tinggi ada sebanyak $38 \%$.

Penelitian Yunita dengan judul Hubungan Antara Pengetahuan Dengan Perilaku Diet Mahasiswa Putri Hasil penelitian menunjukkan bahwa tidak ada hubungan antara pengetahuan dengan perilaku diet pada mahasiswa putri Universitas $(p$-value $=0,43 \%)$. Direkomendasikan kepada mahasiswa putri agar lebih banyak lagi mempelajari tentang pengetahuan terkait diet dan melakukan diet sesuai dengan pengetahuannya.

Hasil penelitian mayoritas responden memiliki pengetahuan rendah tentang diet berjumlah 42 responden (51\%), seluruh responden (100\%) mendapatkan informasi tentang diet. Berarti responden tidak memahami dan tidak mengerti tentang informasi tersebut, atau menganggap informasi yang diterimanya tidak penting dan mayoritas informasi yang didapatkan dari sosial media yang tidak jelas sumbernya dari mana dan tidak dapat dipastikan kebenarannya.

Sikap merupakan reaksi atau respon seseorang yang masih tertutup terhadap suatu stimulus atau objek. Faktor-faktor yang mempengaruhi sikap diantaranya yaitu pengalaman pribadi, pengaruh orang lain yang dianggap penting, media massa, lembaga pendidikan, dan faktor emosional (Wawan, 2011).

Hasil penelitian Di SMA Negeri 5 didapatkan mayoritas responden memiliki sikap positif tentang diet sebanyak 43 responden (52\%), ditemukan $63 \%$ responden memiliki IMT beresiko dan obesitas, responden cenderung bersikap positif dan termotivasi untuk untuk melakukan diet.

Menurut Wawan (2011), tindakan merupakan bentuk perilaku terbuka, karena dapat diamati oleh orang lain dari luar. Praktek memiliki 4 tingkatan yaitu persepsi, respon terpimpin, mekanisme, dan adopsi. Mengenal dan memilih berbagai objek sehubungan dengan tindakan yang akan diambil adalah merupakan praktek tingkat pertama. Setelah itu seseorang dapat melakukan sesuatu sesuai dengan urutan yang benar dab sesuai dengan contoh merupakan indikator praktek tingkat dua. Praktek tingkat tiga dapat dicapai apabila seseorang telat dapat melakukan sesuatu dengan benar secara otomatis. Atau sesuatu itu sudah 
merupakan kebiasaan. Praktek tingkat tertinggi apabila sudah adaptasi yaitu praktek atau tindakan yang sudah berkembang dengan baik.

Hasil penelitian ini sejalan dengan penelitian yang dilakukan oleh Iin Indahwati tahun 2011 yang berjudul Hubungan persepsi Gambaran Tubuh Dengan Perilaku Diet Pada Remaja Putri Di SMK Negeri 2 Godean Sleman, bahwa responden yang paling banyak mempunyai perilaku diet tinggi yaitu 72 orang $(83,7 \%)$ dan yang paling sedikit berperilaku diet sedang yaitu 14 orang $(16,3 \%)$.

Hasil penelitian Di SMA Negeri 5 didapatkan mayoritas responden melakukan diet sebanyak 58 responden $(71 \%)$. 63\% responden memiliki berat badan beresiko dan berlebih, sehingga mereka merasa tidak percaya diri dengan badannya, sebagian besar remaja putri berkeinginan untuk tampil sempurna yang sering kali diartikan dengan memiliki tubuh yang proposional yang merupakan idaman bagi mereka walaupun tidak benar apa pola diet yang dilakukan remaja. Namun faktor lain remaja melakukan diet dengan adanya saran dari orang tua untuk mendukung anaknya melakukan diet sebanyak (63\%).

Hasil penelitian Elisabeth dengan judul Pengaruh Media Massa Terhadap Perilaku Diet Tahun 2020 Dari beberapa studi yang telah dipaparkan terbukti bahwa media massa berpengaruh pada perilaku diet. Contoh dari media massa yang membuktikan hal tersebut terdapat pada media sosial contohnya twitter, media cetak yaitu majalah, dan media televisi.

\section{SIMPULAN DAN SARAN}

Dari Uraian diatas dapat disimpulkan bahwa responden di SMA Negeri 5 Pekanbaru mayoritas responden memiliki pengetahuan rendah tentang diet, sikap yang positif tentang diet dan mayoritas responden melakukan diet

Saran dari peneliti diharapkan pihak sekolah di SMA Negeri 5 Pekanbaru agar lebih memperhatikan remaja yang melakukan diet agar prestasi belajar tidak tergganggu serta tercapainya proses dan tujuan pendidikan. Upaya yang dapat dilakukan salah satunya dengan memberikan penyuluhan kesehatan seputar kesehatan reproduksi bagi remaja secara berkala dengan bekerja sama pada pihak Puskesmas atau Instansi pendidikan kesehatan 


\section{DAFTAR PUSTAKA}

Abdurrahman, Fadlullah (2014). Faktor-faktor pendorong perilaku diet tidak sehat pada wanita usia dewasa awal studi kasus pada mahasiswa universitas mulawarman tahun 2016. http://ejournal.psikologi.fisipunmul.ac.id/site/wp-content/uploads/2014/08/jurnal\%20fix\%20(08-29-1412-24-35).pdf. (Di akses 8 Januari 2018 pukul $22.00 \mathrm{WIB}$ ).

Alhadar, A. Indiasari, R. Yustini.2014. Hubungan Antara Body Image Dan Perilaku Diet Dengan Overweight pada Remaja Di Sma Katolik Makassar.Makassar: Program Studi Ilmu Gizi Fakultas Kesehatan Masyarakat Universitas Hasanuddin

Anastasia Lintang, dkk (2015) Hubungan Citra Tubuh Dengan Perilaku Diet Pada Remaja Putri Di SMA Negeri 9 Manado, https://ejournal.unsrat.ac.id/index.php/jkp/article/viewFile/8144/7704 (Diakses 10 Januari 2018pukul 20.30 WIB).

Ayuningtyas, P.2012. Hubungan Faktor Individu dan Lingkungan dengan Perilaku Diet pada Mahasiswi Prodi Gizi dan Ilmu Komunikasi UI Angkatan 2009 Tahun 2012.Depok : Program Studi Gizi Fakultas Kesehatan Masyarakat Universitas Indonesia.

Dephinto, Yonaniko, 2017, Hubungan body image dengan perilaku diet pada remaja putri tahun 2016 kelas X dan XI SMKN 2 Padang tahun 2017. http://joernal.umsb.ac.id/index.php/menarailmu/article/viewFile/162/142. (Di akses 8 Januari 2018 pukul 19.45 WIB).

Elisabeth Kristina Ari Nugrahanti, 2020, Pengaruh Media Massa Terhadap Perilaku Diet: Systematic Revie, file:///C:/Users/USER/Downloads/10513068-1-PB\%20(2).pdf, (Di akses 18 Oktober 2021 pukul 17.15 WIB).

Hanum, et al: 2014. Pengaruh body dissatisfaction dan self-esteem dengan perilaku diet mahasiswi universitas " $x$ " serta tinjauan dalam islam tahun 2014. $\quad$ http://academicjournal.yarsi.ac.id/index.php/Jurnal-OnlinePsikogenesis/article/download/51/pdf. (Di akses 8 Januari 2018 pukul 19.00 WIB).

Hidayat, Aziz Alimul, 2011. Metodelogi Penelitian Kebidanan Teknik Analisis Data. Jakarta: Salemba Medika

Notoatdmojo, Soekidjo ,2012. Metodologi Penelitian Kesehatan. Jakarta : Rineka Cipta.

Rahmi Pramulia Firi, (2014) Pengaruh Teman Sebaya, Pengetahuan, Media Masa Terhadap Perilaku Diet Mahasiwi Stikes Payung Negeri Pekanbaru, http://ejournal.lldikti10.id/index.php/endurance/article/viewFile/1487/936, (Diakses 10 Januari 2018 pukul 20.40 WIB). 
Syarafina, A., \& Probosari, E. (2014) Hubungan Eating Disorder Dengan Status Gizi Pada Remaja Putri Di Modeling Agency Semarang. (http://ejournals1.undip.ac.id/index.php/jnc/. Diakses pada tanggal 16 September 2014).

Wawan dan Dewi M. 2011. Teori \& Pengukuran Pengetahuan, Sikap, Perilaku Manusia, Yogyakarta : Nuhaha Medika.

Yunita Ariska, Teuku Tahlil, 2018, Hubungan Antara Pengetahuan Dengan Perilaku Diet Mahasiswa Putri, Http://Jim.Unsyiah.Ac.Id/Fkep/Article/View/9664, (Di akses 18 Oktober 2021 pukul 17.30 WIB). 